\title{
Centrality Measure in Weighted HPAI Transmission Network: The case of the highly pathogenic H5N1 avian influenza Virus in Gimje, South Korea in 2008
}

\author{
Hyungjin Lee $\cdot$ Kyo Suh* ${ }^{*}$ Namsu Jung ${ }^{* *}$ Inbok Lee* $\cdot$ Ilhwan Seo \\ Woonkyung Moon $^{* \star *} \cdot$ Jeong-Jae Lee*
}

\author{
가중 HPAI 확산 네트워크에서 중심성 분석: \\ 2008년 한국 김제 지역의 HPAI 발병 사례를 중심으로 \\ 이형진 • 서교 ${ }^{*}$ 정남수 ${ }^{*}$ 이인복 ${ }^{*}$ 서일환 • 문운경 ${ }^{* \star}$ - 이정재 ${ }^{*}$ \\ Graduate School, Seoul National University \\ *Department of Landscape Architecture and Rural System Engineering, Seoul National University \\ ${ }^{* *}$ Department of Rural Construction Engineering, Kongju National University \\ ${ }^{* * *}$ Animal Plant \& Fisheries Quarantine \& Inspection Agency
}

\begin{abstract}
HPAI 질병 확산의 매개체가 된다. 농가들의 가금관련업체 이용 정보를 이용하면 농가간의 연결을 확인할 수 있고 HPAI 확산 가중 네트워크를 구성할 수 있다. 네트워크 분석중 중 심성 측정은 질병에 취약하거나 타 농가에 영향력이 큰 역할을 하는 농가를 분석하는 방법으로 HPAI 초기 확산을 통제하 는 방법으로 이용된다. 단, HPAI 바이러스는 네트워크의 연결선 가중치에 따라서 확산 경로가 달라질 수 있다. 기존의 분 석 방법은 확산 경로에 있어 대치되는 연결선의 강도와 연결선의 수 중 하나만을 고려하기 때문에 질병 확산을 정확히 모 의하는데 한계가 있다. 그래서 본 연구에서는 2008년 발병한 한국 김제 지역의 39 개 농가를 대상으로 가금관련업체 이용 자료를 적용한 HPAI 확산 네트워크에 연결선의 가중치에 지수를 적용하는 방법으로 기존의 방법과 결과를 비교했다. 이 자료는 가금 산업 네트워크의 한국 지역 농가 적용성을 평가 할 수 있을뿐만 아니라 추후 잠재적인 질병 발병 차단을 위 한 정보 제공에 중요한 역할을 할 것이다.
\end{abstract}

Key words : Businesses; HPAI; Poultry Industry Network; Social Network Analysis, Poultry Industry Network

\section{Introduction}

Since the outbreak of highly pathogenic avian influenza (HPAI, H5N1) on poultry premises and in live animal markets in Guangdong Province, China in 1996, these viruses have spread quickly into other countries and now has occured repeatedly in more than 60 countries around the world (WHO, 2012). The fatality rate of the HPAI viruses has been very high for the birds, which, in turn,

Corresponding author : Suh, Kyo

Tel : 02-880-4715

E-mail : kyosuh@snu.ac.kr has also caused huge economic losses for the industry (Alexander, 2000; Bin et al., 2010; Ahemd et al., 2010; Martinez et al., 2011). An outbreak of the viruses in any part of a country can be a serious threat to its neighboring countries as the viruses are transmitted via migratory birds. Since their first outbreak in 2003, a total of 219 cases have been reported in Korea, and the creation of preventive measures against these viruses is viewed as an urgent matter (NVR, 2008; Lee et al., 2008; Kim et al., 2010).

A wide variety of mutations of the HPAI makes it impossible to stop the spread using preventive vaccines 
alone (David, 2006). It takes much time to confirm the initial outbreaks and to take the necessary measures because of the latent periods of the viruses. In addition, current collective and large-scale poultry premises will continue to suffer enormous losses, if neighboring premises within a certain radius from the outbreak point are completely blocked without proper analysis of the reasons for the spread, as is the current practice (NVR, 2008). Therefore, it is necessary to analyze possible elements that are responsible for creating the routes of the HPAI spread and establish effective preventive measures that focus on areas that can minimize possible losses (Newman, 2002).

Social Network Analysis (SNA), which utilizes network and graphical theories, is based on nodes and ties between the nodes. SNA is widely used to analyze the spread of diseases, because the nodes and the ties can refer to diseases and the vehicles of the diseases, respectively (Bell et al., 1999; Kao et al., 2006; Lee et al., 2009; Waret-Szkuta et al., 2011, Perez et al., 2011)

Stock movement between poultry premises is the main cause of the spread of livestock these diseases (Kao et al., 2006; Ortiz-Pelaez et al., 2006; Ferguson, 2001; VanKerkhovea et al. 2009) In particular, poultry-related businesses and personnel entering the premises have the potential to carry the diseases to neighboring premises or markets (Henzler et al., 2003. Wee et al., 2006, James et al., 2007) Of particular concern are businesses that visit these poultry premises regularly since they can be the main carriers of the HPAI viruses between the premises. In Korea, personnel or vehicles of businesses for shipping and receiving, poultry waste treatment, feeds and medicines have access to the premises. Therefore, the premises that use the same businesses are in danger of spreading the HPAI viruses amongst one another (NVR, 2008). To study this spread, poultry network databases in Great Britain have been established and designed with alert systems and then been used for various studies (Dent et al., 2008; Sharkey et al., 2008; Nickbakhsh et al., 2011).

In this study, the degree of importance placed on the transmission causes was determined through logistic regression analysis using information on the poultry-related businesses used by 98 premises which were epidemiologically investigated during the outbreak in 2008. A network was established based on the survey results and the centrality measure of SNA was used. Taking the 2008 outbreak case into consideration, effective measurements were proposed to prevent the HPAI viruses from spreading at their earliest stages.

\section{Materials and Method}

\section{Sources of data}

The HPAI virus outbreak, which occurred for the first time in South Korea in the Gimje district in 2008, lasted for 42 days with 33 cases confirmed nationally (NVR, 2008). Compared with previous cases, the duration of the infection decreased while the number of infections increased, indicating that the disease spread rapidly in a very short time - a deviation from in the usual pattern. In the Gimje district, there was a high density of poultry premises with large-scale businesses surrounding them; therefore, the area was situated in a high risk environment when the HPAI virus occured.

Figure 1 shows that the infected and non-infected premises are concentrated within a 3 kilometer radius. Many of the 39 premises used the same businesses for goods and services with frequent contact among related personnel and vehicles. In 2008, 12 out of the 39 premises were affected by the HPAI virus. Officials at the Epidemiological Investigation Department of the Korea National Veterinary Research and Quarantine Service conducted investigations to identify possible transmission vectors among the premises. They conducted more than five investigations during a four-month period after the outbreak of the disease and they collected information on the activities of the businesses including shipping and receiving, poultry waste treating, feed, and medicines that the 39 premises utilized.

Several local businesses are part of the poultry business in South Korea. Shipping and receiving businesses transport poultry, poultry waste treatment businesses treat waste regularly, and feed and medicine businesses supply feed and regularly check on the hygienic condition of the poultry. A network can be established using data and information on the movements between the poultry premises and these businesses. There have been several attempts to establish networks on the spread of livestock diseases (Ortiz-Pelaez et al., 2006; Sharkey et al., 2008; 


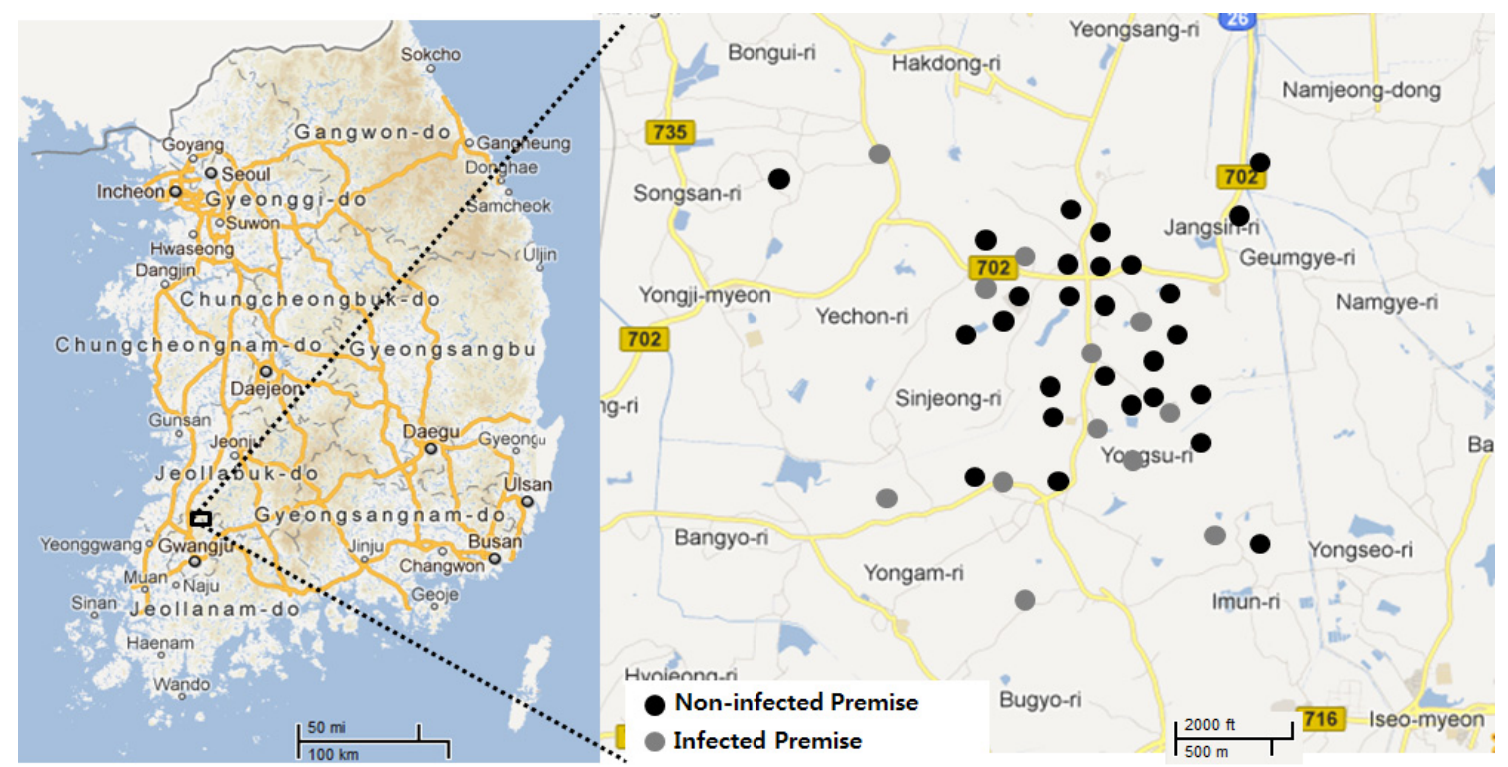

Figure 1 Location of 39 premises in Gimje, South Korea.

Sema et al., 2011), and these attempts have created links between the locations of the premises and the associated businesses including markets, slaughterhouses, and other local businesses. However, the influence of these businesses on the spread of disease between premises can only be shown indirectly, as illustrated in Figure 2(a). In other words, the links between premises are made indirectly, as each premise has direct links only to its own associated businesses.

Visits to the premises by businesses personnel, who also visited other premises, can be the direct vector of the spread of the disease. A complete network with ties between the premises using the same businesses only, and an analysis of the network will confirm the route of the spread of disease as shown in Figure 2(b). The network

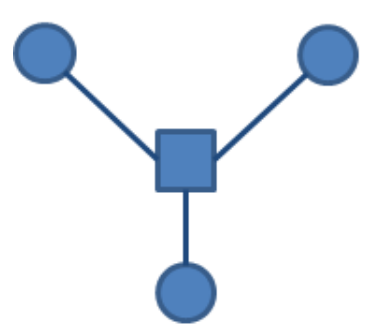

(a)

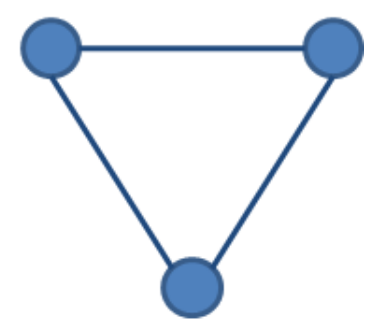

(b)
Figure 2 Network (a) with and (b) without a hub. enables a comparison of the roles among the premises during the spread of the disease. In this study, two networks - with and without the businesses - were established and their results were compared.

\section{Centrality measure}

Conducting a centrality measure is one of the most important aspects of the SNA. In the SNA, the centrality measure shows the key characteristics of a network in terms of values. Degree centrality calculates the number of ties linked to one node. Betweenness centrality assesses the extent to which one node lies on the shortest path between two other nodes. From these methods, a node that acts as a hub linking other nodes in a network can be found. Freeman (1978) derived the centrality concept from the idea of a binary network. In a binary network, the strength of ties is identical; therefore, centrality can be derived using only the number of ties. Unfortunately, however, current studies using the existing method apply the centrality theory on the weighted networks and focus too heavily on the strength of the ties. (Brandes, 2001, Newman, 2001; Borgatti, 2006). To find the centrality in a weighted network, the difference in the importance between the strength and the number of ties requires careful observation when the spread of disease is simulated between two nodes. For instance, the shortest path of the 
Hyungin Lee $\cdot$ Suh Kyo $\cdot$ Namsu Jung $\cdot$ Inbok Lee $\cdot$ Ilhwan Seo $\cdot$ Woonkyung Moon $\cdot$ Jeong-Jae Lee

disease transmission route should be chosen from direct but weak ties between two nodes, or indirect but strong ties. The HPAI routes of transmission can change with the strength or number of ties; therefore, the two cases should be considered carefully.

Opsahl (2010) proposed a general rule for determining the centrality of a weighted network by regulating the weight of ties using index $\alpha$. This is a reasonable approach considering the nature of a network which deals with the spread of disease using the strength and the number of ties. The disease spreads in the direction of the shorter distance between two nodes if the index $\alpha$ lies between 0 and 1 , and in the direction of the overall higher strength of ties, without regard to the number of ties between two nodes if the index $\alpha$ lies above 1 . Application of this index to the HPAI spread enables the analysis of the characteristics of the spread. In this study, the degree and betweenness centrality of the HPAI transmission network were analyzed for indexes of $0,0.5$, 1 and 1.5, and centrality differences between infected and total premises were calculated.

\section{Results and Discussion}

\section{Probability Analysis}

A total of four businesses - shipping and receiving, poultry waste treatment, feed, and medicine - were identified as vectors of the HPAI transmission. Statistical associations with the four businesses were determined using multivariable logistic regression, with the outbreak of HPAI as a dependent variable and visits by businesses associated with infected premises as a predictor variable based on a survey conducted on the 98 premises in 2008. Results of the logistic model are shown in Table 1. The odds ratio is a measurement of the scale affecting the diseases. The odds ratio of each business was calculated using probability analysis.

OR, odds ratio; s.e. OR, standard error of the odds ratio

SRB, shipping and receiving businesses; WTB, poultry waste treatment businesses; MDB, medicine businesses; FB, feed businesses

Compared to other businesses, the reliability for the poultry waste treatment business was low with a p-value of 0.302. It was confirmed that the waste treatment business had little effect on the spread of HPAI in 2008, as the frequency of visits to the premises by this business was low (NVR, 2008). The logistic model with the other three businesses is expressed as follows,

$$
\begin{aligned}
Z= & -2.578+0.0920 \times(A)+0.2373 \times(B) \\
& +1.242 \times(C)+2.317 \times(D)
\end{aligned}
$$

(A) : visit by shipping and receiving businesses (yes/no)

(B) : visit by poultry waste treatment businesses (yes/no)

(C) : visit by medicines businesses (yes/no)

(D) : visit by feed businesses (yes/no)

$$
P=\frac{1}{1+e^{-Z}}
$$

where $P$ refers to the influence between two premises. A weighted network consists of these $P$ s. The network includes the businesses have 108 nodes and 144 ties, with an average of 1.39 ties per node. The 108 nodes consist of 39 premises, 39 shipping and receiving businesses, 12

\begin{tabular}{|c|c|c|c|c|c|c|}
\hline & \multicolumn{3}{|c|}{ With 4 Businesses } & \multicolumn{3}{|c|}{ With 3 Businesses } \\
\hline & OR & s.e. $\mathrm{OR}$ & p-value & OR & s.e. OR & p-value \\
\hline$\beta_{0}$ & -2.780 & 0.805 & 0.001 & -2.215 & 19.024 & 0.000 \\
\hline$\beta_{1}(\mathrm{SRB})$ & 2.192 & 0.784 & 0.005 & 2.384 & 9.403 & 0.002 \\
\hline$\beta_{2}(\mathrm{WTB})$ & 0.866 & 0.839 & 0.302 & & & \\
\hline$\beta_{3}(\mathrm{MDB})$ & 1.794 & 0.670 & 0.007 & 1.879 & 7.974 & 0.005 \\
\hline$\beta_{4}(\mathrm{FB})$ & 2.323 & 0.774 & 0.003 & 2.385 & 9.140 & 0.003 \\
\hline
\end{tabular}
animal medicine businesses and 13 feed businesses. There

Table 1 Odds ratios of premises and their associated businesses 
Table 2 Degree centrality scores of premises when different values of $\alpha$ are used

\begin{tabular}{cc|cc}
\hline \multicolumn{2}{c|}{ network with 108 nodes } & network with 39 nodes \\
\hline \hline 39 Premises degree & 1.73 & 39 Premises degree & 7.51 \\
12 Infected premises degree & 1.83 & 12 Infected premises degree & 8.42 \\
Infected premises / all premises & 1.06 & Infected premises / all premises & 1.12 \\
\hline
\end{tabular}

is no direct tie between the premises, but only ties between the premises and the businesses.

The network consisted only of the premises that had 39 nodes and 324 ties with an average of 8.31 ties per node. More than two visits by vehicle or personnel simultaneously made to two premises formed multiple ties, and the maximum number of such ties was three. Visits for stock movement, feed, and medicine were 46 ties $(14.2 \%)$, and 139 ties $(42.9 \%), 139$ ties $(42.9 \%)$, respectively. Twelve out of 39 premises were infected $(30.8 \%)$, and the 39 premises linked to each other formed a closed and weighted network.

\section{Centrality measure as the index}

The centrality ratio of the 12 infected premises against the 39 premises for the networks with 108 and 39 nodes were 1.06 and 1.12 respectively, as shown in Table 2. The premises with a higher centrality ratio had a greater chance of being infected.

Table 3 and 4 show the results of the degree and betweenness centralities when the indexes of $0,0.5,1.0$ and 1.5 were used for the network with 39 nodes. The values in parentheses are the centrality ratio. Node Numbers 1 12 and 13 39 refer to infected and non-infected premises respectively. For example, the degree centrality ratio of the number. 1 premise is 21 as the index is 0 . The centrality ratio of the 12 infected premises against the 39 premises is IP/All(Infected premises/ All premises). In Tables 3 and 4 the lower the index, the larger the centrality ratio of the infected premises(IP) against all premises(All).

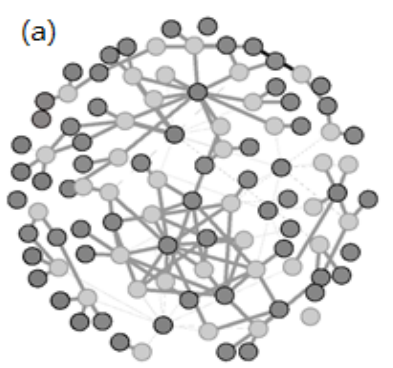

(c)

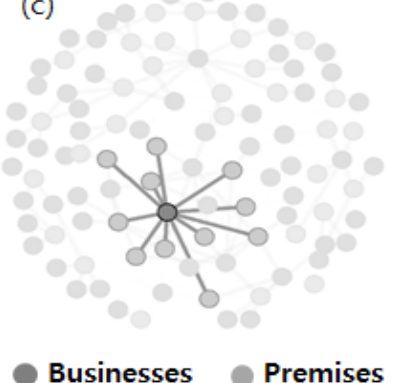

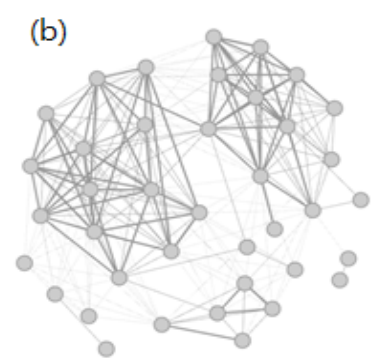

(d)

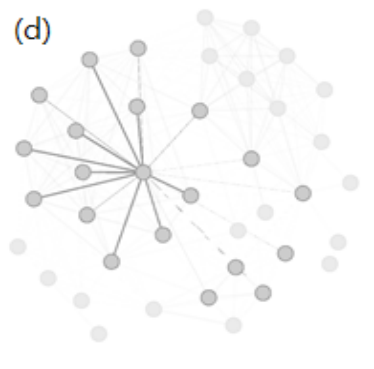

Figure 3 HPAI transmission network (A) with (108 nodes) and (B) without businesses (39 nodes). (C) Ties between premises and businesses in 108 nodes (D) Ties between the premises in 39 nodes. 
Hyungjin Lee $\cdot$ Suh Kyo $\cdot$ Namsu Jung $\cdot$ Inbok Lee $\cdot$ Ilhwan Seo $\cdot$ Woonkyung Moon · Jeong-Jae Lee

Table 3 Ranking of premises according to their degree centrality when different values of $\alpha$ are used

\begin{tabular}{|c|c|c|c|c|c|c|c|c|}
\hline \multirow{3}{*}{$\frac{\text { Rank }}{1}$} & \multicolumn{8}{|c|}{ Degree } \\
\hline & \multicolumn{2}{|c|}{$\alpha=0$} & \multicolumn{2}{|c|}{$\alpha=0.5$} & \multicolumn{2}{|c|}{$\alpha=1.0$} & \multicolumn{2}{|c|}{$\alpha=1.5$} \\
\hline & Infected & $1(21)$ & Infected & 1(16.69) & Infected & $1(13.26)$ & Infected & $11(10.67)$ \\
\hline 2 & Infected & $8(20)$ & Infected & $11(15.68)$ & Infected & $11(12.93)$ & Infected & $1(10.54)$ \\
\hline 3 & Infected & $7(19)$ & Infected & $7(15.10)$ & & $18(12.25)$ & & $18(10.11)$ \\
\hline 4 & Infected & 11(19) & Infected & $8(15.03)$ & Infected & $7(11.99)$ & Infected & $12(9.95)$ \\
\hline 5 & & $37(19)$ & & $18(14.85)$ & Infected & $12(11.90)$ & & $36(9.92)$ \\
\hline 6 & Infected & $4(18)$ & & $37(14.55)$ & & $36(11.64)$ & Infected & $7(9.53)$ \\
\hline 7 & & $13(18)$ & Infected & $12(14.22)$ & & $34(11.43)$ & & $34(9.37)$ \\
\hline 8 & & $18(18)$ & & $34(13.94)$ & Infected & $8(11.30)$ & & $27(8.77)$ \\
\hline 9 & & $39(18)$ & & 13(13.79) & & $37(11.14)$ & & $33(8.72)$ \\
\hline 10 & Infected & $12(17)$ & & $39(13.79)$ & & $27(10.94)$ & & $32(8.70)$ \\
\hline 11 & & $27(17)$ & & $36(13.65)$ & & $32(10.66)$ & & $37(8.53)$ \\
\hline 12 & & $34(17)$ & & $27(13.64)$ & & $13(10.57)$ & Infected & $8(8.49)$ \\
\hline 13 & & $32(16)$ & Infected & $4(13.15)$ & & $39(10.57)$ & & $13(8.10)$ \\
\hline 14 & & $35(16)$ & & $32(13.06)$ & & $33(10.21)$ & & $39(8.10)$ \\
\hline 15 & & $36(16)$ & & $35(12.22)$ & Infected & $4(9.61)$ & & $16(8.07)$ \\
\hline 16 & & $29(14)$ & & $33(11.96)$ & & $16(9.46)$ & Infected & $5(7.84)$ \\
\hline 17 & & $33(14)$ & & $16(11.09)$ & & $35(9.34)$ & & $24(7.84)$ \\
\hline 18 & Infected & $5(13)$ & Infected & $5(10.98)$ & Infected & $5(9.28)$ & & $14(7.58)$ \\
\hline 19 & & $14(13)$ & & $24(10.98)$ & & $24(9.28)$ & & $23(7.58)$ \\
\hline 20 & & $16(13)$ & & $14(10.86)$ & & $14(9.08)$ & & $35(7.13)$ \\
\hline 21 & & $23(13)$ & & $23(10.86)$ & & $23(9.08)$ & Infected & $4(7.02)$ \\
\hline 22 & & $24(13)$ & & $29(9.67)$ & & $21(7.66)$ & & $21(6.12)$ \\
\hline 23 & & $21(12)$ & & 21(9.59) & & $29(6.68)$ & & $29(4.61)$ \\
\hline 24 & & $22(12)$ & & $22(8.66)$ & & $22(6.25)$ & & $22(4.52)$ \\
\hline 25 & & $10(11)$ & & $10(8.05)$ & Infected & $10(5.90)$ & Infected & $3(4.43)$ \\
\hline 26 & Infected & $3(10)$ & Infected & $3(7.62)$ & Infected & $3(5.81)$ & Infected & $10(4.32)$ \\
\hline 27 & Infected & $6(10)$ & & 17(7.39) & & $17(5.46)$ & & $17(4.03)$ \\
\hline 28 & & $17(10)$ & & $20(7.39)$ & & $20(5.46)$ & & $20(4.03)$ \\
\hline 29 & & $20(10)$ & Infected & $6(6.55)$ & Infected & $6(4.29)$ & Infected & $6(2.81)$ \\
\hline 30 & Infected & 2(9) & Infected & $2(5.91)$ & Infected & $2(3.87)$ & Infected & $2(2.54)$ \\
\hline 31 & & $28(9)$ & & $28(5.81)$ & & $28(3.75)$ & & $28(2.42)$ \\
\hline 32 & & $38(9)$ & & $38(5.81)$ & & $38(3.75)$ & & $38(2.42)$ \\
\hline 33 & & $31(5)$ & & $31(3.83)$ & & $31(2.93)$ & & $31(2.24)$ \\
\hline 34 & & $26(3)$ & & $26(2.21)$ & & $26(1.63)$ & & $26(1.20)$ \\
\hline 35 & & $15(2)$ & & $15(1.47)$ & & $15(1.08)$ & Infected & $9(0.89)$ \\
\hline 36 & Infected & $9(1)$ & Infected & $9(0.96)$ & Infected & $9(0.93)$ & & $15(0.80)$ \\
\hline 37 & & $19(1)$ & & $19(0.74)$ & & $19(0.54)$ & & $19(0.40)$ \\
\hline 38 & & $25(1)$ & & $25(0.74)$ & & $25(0.54)$ & & $25(0.40)$ \\
\hline \multirow[t]{4}{*}{39} & & $30(1)$ & & $30(0.74)$ & & $30(0.54)$ & & $30(0.40)$ \\
\hline & All avg & 12.25 & All avg & 9.56 & All avg & 7.51 & All avg & 5.92 \\
\hline & IP Avg & 14 & IP Avg & 10.82 & IP Avg & 8.42 & IP Avg & 6.58 \\
\hline & IP/All & 1.14 & IP/All & 1.13 & IP/All & 1.12 & IP/All & 1.11 \\
\hline
\end{tabular}

Values in parentheses are the centrality ratio. 
Centrality Measure in Weighted HPAI Transmission Network

Table 4 Ranking of premises according to their betweenness centrality when different values of $\alpha$ are used

\begin{tabular}{|c|c|c|c|c|c|c|c|c|}
\hline & \multicolumn{8}{|c|}{ Betweenness } \\
\hline Rank & \multicolumn{2}{|c|}{$\alpha=0$} & \multicolumn{2}{|c|}{$\alpha=0.5$} & \multicolumn{2}{|c|}{$\alpha=1.0$} & \multicolumn{2}{|c|}{$\alpha=1.5$} \\
\hline 1 & Infected & $8(218)$ & & $18(193)$ & & $18(217)$ & & $18(268)$ \\
\hline 2 & Infected & $1(214)$ & Infected & $1(161)$ & Infected & $12(172)$ & Infected & $12(197)$ \\
\hline 3 & & $18(213)$ & Infected & $12(161)$ & & $34(170)$ & & $34(188)$ \\
\hline 4 & Infected & $7(205)$ & & $34(161)$ & Infected & $1(159)$ & Infected & $11(177)$ \\
\hline 5 & & $37(205)$ & & $27(151)$ & & $27(150)$ & Infected & $1(155)$ \\
\hline 6 & Infected & 11(199) & Infected & $11(142)$ & Infected & 11(147) & & $27(152)$ \\
\hline 7 & & 29(197) & & $29(125)$ & Infected & $6(123)$ & & $36(140)$ \\
\hline 8 & Infected & 12(193) & Infected & $4(123)$ & Infected & $4(122)$ & & $33(132)$ \\
\hline 9 & & 27(193) & Infected & $6(123)$ & & $29(122)$ & & $35(126)$ \\
\hline 10 & & $34(193)$ & & $35(120)$ & & $35(121)$ & & $29(124)$ \\
\hline 11 & & 13(189) & & $36(119)$ & & $36(121)$ & Infected & $6(123)$ \\
\hline 12 & & $39(189)$ & & $37(119)$ & & $33(116)$ & & $16(119)$ \\
\hline 13 & & $35(188)$ & & $33(118)$ & & $13(112)$ & & $37(108)$ \\
\hline 14 & Infected & $4(186)$ & & $13(115)$ & & $22(112)$ & Infected & $4(106)$ \\
\hline 15 & & $32(174)$ & & $39(115)$ & & $39(112)$ & & $32(105)$ \\
\hline 16 & & $36(174)$ & Infected & $8(113)$ & & $37(110)$ & & $22(104)$ \\
\hline 17 & & $22(163)$ & & $22(112)$ & & $32(107)$ & & $13(103)$ \\
\hline 18 & Infected & $10(138)$ & & $32(107)$ & Infected & $10(103)$ & & $39(101)$ \\
\hline 19 & & $33(132)$ & Infected & $10(103)$ & & $17(101)$ & Infected & $10(100)$ \\
\hline 20 & & $17(129)$ & & $17(101)$ & & $20(101)$ & & $17(96)$ \\
\hline 21 & & $20(129)$ & & $20(101)$ & Infected & $8(98)$ & & $20(96)$ \\
\hline 22 & Infected & $6(123)$ & Infected & $7(99)$ & Infected & $7(94)$ & Infected & $8(90)$ \\
\hline 23 & Infected & $5(105)$ & & $16(94)$ & & $16(92)$ & & $31(90)$ \\
\hline 24 & & $14(105)$ & & $31(91)$ & & $31(91)$ & Infected & $2(88)$ \\
\hline 25 & & $16(105)$ & Infected & $2(90)$ & Infected & $2(90)$ & Infected & $3(88)$ \\
\hline 26 & & $23(105)$ & Infected & $5(90)$ & Infected & $3(88)$ & Infected & $5(88)$ \\
\hline 27 & & $24(105)$ & & $14(90)$ & Infected & $5(88)$ & Infected & $9(88)$ \\
\hline 28 & Infected & 2(99) & & $23(90)$ & Infected & $9(88)$ & & $14(88)$ \\
\hline 29 & & $26(96)$ & & $24(90)$ & & $14(88)$ & & $19(88)$ \\
\hline 30 & & $31(91)$ & Infected & $3(88)$ & & $15(88)$ & & $23(88)$ \\
\hline 31 & & $21(90)$ & Infected & $9(88)$ & & $19(88)$ & & $24(88)$ \\
\hline 32 & Infected & $3(88)$ & & $15(88)$ & & $21(88)$ & & $28(88)$ \\
\hline 33 & Infected & $9(88)$ & & $19(88)$ & & $23(88)$ & & $38(88)$ \\
\hline 34 & & $15(88)$ & & $21(88)$ & & $24(88)$ & & $15(86)$ \\
\hline 35 & & $19(88)$ & & $26(88)$ & & $26(88)$ & & $21(84)$ \\
\hline 36 & & $28(88)$ & & $28(88)$ & & $28(88)$ & & $26(83)$ \\
\hline 37 & & $38(88)$ & & $38(88)$ & & $38(88)$ & Infected & $7(82)$ \\
\hline 38 & & $25(14)$ & & $25(14)$ & & $25(14)$ & & $25(14)$ \\
\hline \multirow[t]{4}{*}{39} & & $30(10)$ & & $30(10)$ & & $30(10)$ & & $30(10)$ \\
\hline & All avg & 138.38 & All avg & 106.28 & All avg & 106.23 & All avg & 108.69 \\
\hline & IP Avg & 154.66 & IP Avg & 115.08 & IP Avg & 114.33 & IP Avg & 115.16 \\
\hline & IP/All & 1.11 & IP/All & 1.08 & IP/All & 1.07 & IP/All & 1.05 \\
\hline
\end{tabular}

Values in parentheses are the centrality ratio. 


\section{Analysis of the HPAl using the centrality measure}

In the analysis of the HPAI transmission network, centrality varies depending on the inclusion of the businesses. In Figure 2, there is no change in the betweenness centrality, because the shortest direct distances between ties of the two nodes and via the hub are the same. However, their degree centrality is different as shown in Table 1. In the network with 108 nodes, direct HPAI virus transmission between premises is disregarded because only the ties between premises and the businesses are considered. The businesses are common vectors for the transmission of HPAI; therefore the premises visited by the businesses that visit many premises are not only vulnerable to HPAI virus infection, but are also in a strong position to transmit the HPAI virus to other premises. For instance, in the network with 108 nodes, the difference in the degree centrality cannot be shown between premise 'A' linked with a business visiting three premises and premise 'B' linked with a business visiting six premises. In this example, the influence on the transmission by premise ' $\mathrm{B}$ ' is underestimated, because the two premises can have only one tie between them and the businesses. However, in the network with 39 nodes, the degree centrality between the two premises can be compared, because the two can be linked without the business. The degree centrality ratio of the infected premises against the total premises in the 108-node network is lower than that in the 39-node network, which suggests that there are underestimated infected premises, despite their vulnerability to the infection in the 108-node network. A network consisting of only premises may be more suitable in the network analysis when implementing preventive measures for the premises.

Degree and betweenness centralities are useful in locating the key nodes responsible for the transmission of the disease. Determining which are the important nodes can help prevent the disease from spreading at an early stage (Mansley et al., 2003; Ortiz-Pelaez, 2006; Vincent et al., 2011). High centrality indicates that there is a greater chance of the nodes being located near important hubs, and thus becoming vulnerable to infection or affecting other premises. In Tables 3 and 4, the centrality of the infected premises is greater than that of all premises, which confirms that infected premises can be effectively predicted through the centrality measure in the HPAI transmission network using a poultry industry network database.

The premises visited by associated businesses that have many premises as customers are more vulnerable to the HPAI infection. Likewise premises that are visited by various businesses are more vulnerable than the ones that are not. As the index $\alpha$ decreased, the centrality ratio between the infected premises and all premises increased. Although there were some cases to the contrary, the overall centrality of the infected premises increased.

Checking the representative number of premises, the compatibility of the index could be identified in the centrality measure. According to the index, the centrality of the premises could change. For example, the degree centrality of the infected premises 4 and 7 , and the betweenness centrality of the infected premises 1 and 8 became relatively higher compared to that of the non-infected premises 27 and 34 as the index $\alpha$ decreased, which means that the transmission route can be traced more accurately when $\alpha=0$ than when $\alpha=1.5$. The centrality of the infected premises is greater than non-infected premises when $\alpha=1$, the existing method. In other words, the influence on the spread of the HPAI virus by visiting businesses is independent; therefore, the strength of the ties due to sharing of different types of businesses among the premises is not an important cause of the spread. For instance, the ties between premises dealing with only a medicine business visiting many premises may be more critical in the spread of the HPAI virus than the ties between premises sharing activities related to shipping/receiving, medicine, and feed businesses simultaneously. The betweenness centrality shows the same results. The ties with weaker but fewer intermediate nodes may be the shortest or optimum route for spreading the disease compared to the ties indirectly linked with more intermediate nodes. Thurs, it is more effective to calculate a network centrality considering the number of ties than the strength of nodes using indexes smaller than 1 when premises that are vulnerable to the HPAI virus are to be detected using the businesses' activity data (Nickbakhsh et al., 2011)

The HPAI virus spreads quickly and has a latent period; therefore there will be some problems in establishing preventive measures (Kim et al., 2010), if the businesses' activities are analyzed after an outbreak of the virus is 
confirmed. The causes of HPAI virus transmission become complicated by the movements of the residents and visits by the businesses in the study area where many premises are clustered together. There is a great significant possibility that an outbreak of the HPAI in any premise may spread rapidly and continually to other premises. Concentrated areas are also linked with other areas; therefore, failure to stop the spread of the HPAI virus at an early stage will cause substantial damage to the industry. However, the damage can be effectively reduced if the information on the businesses is available and the premises vulnerable to the HPAI virus are identified through the centrality measure.

\section{Conclusion}

In this study, a network was established to simulate the spread of the HPAI virus using information and data on the periodic activities carried out by businesses in areas with a cluster of poultry premises in the Gimje district, South Korea. Frequent visits to poultry premises by associated businesses will accelerate the spread of the HPAI virus. Considering this fact when anlyzing the centrality of a network, this study uses adjusted indexes of ties to bring more meaningful results than existing centrality measures of the weighted network.

We also found that the centrality measure for the infected premises were generally high. This confirms that the centrality measure using information and data on periodic access to premises by associated businesses can be applied to the situation in Korea with respect to tracing HPAI virus infected premises in concentrated areas. It is believed that the results can be used to provide basic information for the establishment of an effective forecasting system, as has been done with the Poultry Industry Network Database in Great Britain. It is also expected that a more reliable HPAI Transmission Network can be established when additional investigations on the causes of the spread of HPAI are carried out in the future.

This work was carried out with the support of "Cooperative Research Program for Agriculture Science \& Technology Development (Project No. PJ008996)" Rural Development Administration, Republic of Korea.

\section{References}

1. Ahmed S. S. U., A.K. Ersbøll, P. K. Biswas, J. P. Christensen, 2010, The space-time clustering of highly pathogenic avian influenza (HPAI) H5N1 outbreaks in Bangladesh, Epidemiology and Infection, $138,843-852$.

2. Alexander D. J., 2000, A review of avian influenza in different bird species. Veterinary Microbiology, 74, $3-13$.

3. Bell, D. C., J. S. Atkinson, J. W. Carlson, 1999, Centrality measures for disease transmission networks., Social Networks, 21, 1-21.

4. Bin W., C. Wang, G. Dong, Y. Guo, D. L. Nolte, T. J. Deliberto, J. Xu, M. Duan, H. He, 2010, New Evidence Suggests Southern China as a Common Source of Multiple Clusters of Highly Pathogenic H5N1 Avian Influenza Virus, The Journal of Infectious Disease, 202, 452-458.

5. Borgatti S. P., K. Carley, D. Krackhardt, 2006, Robustness of centrality measures under conditions of imperfect data. Social Networks, 28, $124-136$.

6. Brandes U., 2001, A Faster Algorithm for Betweenness Centrality. Journal of Mathematical Sociology, 25, 163 - 177.

7. David E. S., 2006, Principles for Vaccine Protection in Chickens and Domestic Waterfowl against Avian Influenza -Emphasis on Asian H5N1 High Pathogenicity Avian Influenza, Annals of the New York Academy of Sciences, 1081, 174-181.

8. Jennifer E. D., R. R. Kao, I. Z. Kiss, K. Hyder, M. Arnold, 2008, Contact structures in the poultry industry in Great Britain: exploring transmission routes for a potential avian influenza virus epidemic. BMC Veterinary Research, 4, 27.

9. Ferguson N. M., C. A. Donnelly, R. M. Anderson, 2001, Transmission intensity and impact of control policies on the foot and mouth epidemic in Great Britain. Nature, 413, 542-548.

10. Freeman, L. C., 1978/9, Centrality in social networks conceptual clarification. Social Networks, 1, 215-239.

11. Henzler D. J., D. C. Kradel, S. Davison, A. F. Ziegler, D. Singletary, P. Debok, A. E. Castro, H. Lu, R. Eckroade, D. Swayne, W. Lagoda, B. Schmucker, A. Nesselrodt, 2003, Epidemiology, 
Hyungjin Lee $\cdot$ Suh Kyo $\cdot$ Namsu Jung $\cdot$ Inbok Lee $\cdot$ Ilhwan Seo $\cdot$ Woonkyung Moon $\cdot$ Jeong-Jae Lee

production losses, and control measures associated with an outbreak of avian influenza subtype H7N2 in Pennsylvania (1996-98). Avian Diseases, 47, 1022-1036.

12. James T., T. Garske, I. Chis-Ster, J. Guitian, D. Pfeiffer, L. Snow, J. Wilesmith, N. M. Ferguson, A. C. Ghani, 2007, Control of a highly pathogenic H5N1 avian influenza outbreak in the GB poultry flock, Proc. R. Soc. B, 274, 2287-2295.

13. Kao R. R., L. Danon, D. M. Green1, I. Z. Kiss, 2006, Demographic structure and pathogen dynamics on the network of livestock movements in Great Britain. Proceedings Biological Science, 273, 1999-2007.

14. VanKerkhovea M. D., S. Vong, J. Guitian, D. Holl, P. Mangtani, S. Sane, A. C. Ghani, 2009, Poultry movement networks in Cambodia: Implications for surveillance and control of highly pathogenic avian influenza (HPAI/H5N1), Vaccine, 27, 6345-6352.

15. Martinez M., A. M. Perez, A. DelaTorre, I. Iglesias, J. M. Sanchez-Vizcaino, M. J. Munoz, 2011, Evaluating surveillance in wild birds by the application of risk assessment of avian influenza introduction into Spain, Epidemiology and Infection, 139, 91-98.

16. Mansley L. M., P. J. Dunlop, S. M. Whiteside, R. G. H. Smith, 2003, Early dissemination of foot-andmouth disease virus through sheep marketing in February 2001, The Journal of veterinary record, 153, 43-50.

17. National Veterinary Research \& Quarantine Service, 2008, Ministry for Food, Agriculture, Forestry and Fisheries. Republic of Korea, 2008 HPAI Epidemiological investigation report, Seoul.

18. Newman, M. E. J., 2001, Scientific collaboration networks. II. Shortest paths, weighted networks, and centrality. Physical Review E, 64, 016132.

19. Newman, M. E. J., 2002, Spread of epidemic disease on networks. Physical Review E, 66, 016128.

20. Ortiz-Pelaez A., D. U. Pfeiffer, R. J. SoaresMagalhaes, F. J. Guitian, 2006, Use of social network analysis to characterize the pattern of animal movements in the initial phases of the 2001 foot and mouth disease (FMD) epidemic in the UK, Preventive Veterinary Medicine, 76, 40-55.
21. Perez A., M. AlKhamis, U. Carlsson, B. Brito, R. Carrasco-Medanic, Z. Whedbee, P. Willeberg, 2011, Global animal disease surveillance, Spatial and Spatio-temporal Epidemiology, 2, 135-145.

22. Nickbakhsh S., L. Matthews, P. R. Bessell, S. W. J. Reid, R. R. Kao, 2011, Generating social network data using partially described networks: an example informing avian influenza control in the British poultry industry, BMC Veterinary Research, 7, 16

23. Sharkey K. J., R. G. Bowers, K. L. Morgan, S. E. Robinson, R. M. Christley, 2008, Epidemiological consequences of an incursion of highly pathogenic H5N1 avian influenza into the British poultry flock. Proceedings Biological Sciences, 275, 19-28.

24. Lee S. S., D. K. P. Tam, R. L. M. Ho, K. H. Wong, 2009, Social network methodology for studying HIV epidemiology in men having sex with men, Journal of Infection and Public Health, 2, 177-183.

25. Opsahl T., F. Agneessens, J. Skvoretz, 2010, Node centrality in weighted networks: Generalizing degree and shortest paths, Social Networks, 32, 245-251.

26. Kim T., W. Hwang, A. Zhang, S. Sen, M. Ramanathan, 2010, Multi-agent modeling of the South Korean avian influenza epidemic, BMC Infectious Diseases, 10, 236.

27. Vincent M., X. Zhou, E. Marshall, B. Jia, G. Fusheng, M. A. FrancoDixon, N. DeHaan, D. U. Pfeiffer, R. J. S. Magalhães, M. Gilbert, 2011, Risk-based surveillance for avian influenza control along poultry market chains in South China: The value of social network analysis, Preventive Veterinary Medicine, 102, 196-205.

28. Waret-Szkuta A., A. Ortiz-Pelaez, D. U. Pfeiffer, F. Roger, F. J. Guitian, 2011, Herd contact structure based on shared use of water points and grazing points in the Hig hlands of Ethiopia, Epidemiology and Infection, 139, 875-885.

29. Wee S. H., C. H. Park, H. M. Nam, C. H. Kim, H. Yoon, S. J. Kim, E. S. Lee, B. Y. Lee, J. H. Kim, J. H. Lee, C. S. Kim, 2006, Outbreaks of highly pathogenic avian influenza (H5N1) in the Republic of Korea in 2003/04. The Veterinary Record, 158, 341-344.

30. World Health Organization (WHO). H5N1 avian influenza: Timeline of major events reported to $\mathrm{WHO}$, 
14 Mar 2012. (http://who.int/influenza/human_animal interface/avian_influenza/H5N1_avian_influenza_update1 40312.pdf), Accessed 14 Mar 2012.

31. Lee Y. J., Y. K. Choi, Y. J. Kim, M. S. Song, O. M. Jeong, E. K. Lee, W. J. Jeon, W. Jeong, S. J. Joh, K. S Choi, M. Her, M. C. Kim, A. Kim, M. J. Kim, E. h. Lee, T. G. Oh, H. J. Moon, D. W. Yoo, J. H. Kim, M. H. Sung, H. Poo, J. H. Kwon, C. J. Kim, 2008, Highly Pathogenic Avian Influenza Virus
(H5N1) in Domestic Poultry and Relationship with Migratory Birds, South Korea, Emerging Infectious Diseases, 14, 487-490.

접 수 일: (2012년 11월 9일)

수 정 일: (1차: 2012년 11월 26일, 2차: 12월 5일)

게재확정일: (2012년 12월 5일)

- 3인 익명 심사필 